\title{
KONTRAK PEMBIAYAAN MURABAHAH DAN MUSAWAMAH
}

\author{
Rahmat Ilyas
}

\begin{abstract}
Islamic bank is a financial intermediary (Intermediary Financial Institution) whose operations are free from elements that are forbidden by Islam, namely gambling, Gharar, Riba, Ryswah, and falsehood. thus different from conventional banks whose. operations using the principles of interest by most scholars say the same as usury. The element that distinguishes Islamic bank with a conventional bank is the necessity of Shariah Supervisory Board (DPS) under the auspices of the National Sharia Council of the Indonesian Ulema Council (DSN-MUI). Shariah Supervisory Board (DPS) is to monitor the operation of the bank and the products it releases in order to remain in accordance with the provisions of Shari'ah. Murabaha is a contract of sale of goods by the price of the goods plus an agreed profit margin. Based on the bank's sale and purchase agreement to buy the goods ordered by and sold to customers. Bank selling price is the purchase price of the supplier plus an agreed profit.
\end{abstract}

Keywords: Bank, Dewan Pengawas Syariah, Murabahah

\section{A. Pendahuluan}

Perbankan dalam kehidupan suatu negara adalah salah satu agen pembangunan (agent of development). hal ini dikarenakan adanya fungsi utama dari perbankan itu sendiri yaitu sebagai lembaga yang menghimpun dana dari masyarakat dalam bentuk simpanan dan menyalurkan kembali kemasyarakat dalam bentuk kredit atau pembiayaan. fungsi inillah yang lazim disebut sebagai intermediasi keuangan (financial Intermediary Function) (Anshori, 2008 : 3).

Bank syariah merupakan lembaga intermediasi keuangan (financial Intermediary Institution) yang kegiatan operasionalnya bebas dari unsur-unsur yang dilarang oleh islam, yaitu maisir, Gharar, Riba, Ryswah, dan Bathil. 
dengan demikian berbeda dengan bank konvensional yang kegiatan operasionalnya menggunakan prinsip bunga yang oleh sebagian besar ulama dikatakan sama dengan riba.

Bank sebagai lembaga perantara jasa keuangan (financial Intermediary) yang tugas pokoknya adalah menghimpun dana dari masyarakat, diharapkan dengan dana dimaksud dapat memenuhi kebutuhan dana pembiayaan yang tidak disediakan oleh dua lembaga sebelumnya baik lembaga negara mapun swasta.

Dalam kegiatan penyaluran dana bank syariah melakukan investasi dan pembiayaan. disebut investasi karena prinsip yang digunakan adalah prinsip penanaman dana atau penyertaan, dan keuantungan akan diperoleh bergantung pada kinerja usaha yang menjadi obyek penyertaan tersebut sesuai dengan nisbah bagi hasil yang diperjanjikan sebelumnya. disebut pembiayaan karena bank syariah menyediakan dana guna membiayai kebutuhan nasabah yang memerlukannya dan layak memperolehnya.

Pembiayaan yang diberikan kepada nasabah tidak hanya diselesaikan dengan hanya mudharabah dan musyarakah. Namun Islamic Banking dapat juga menjalankan pembiayaan dengan akad jual beli dan sewa. Pada akad jual beli dan sewa, Islamic Banking akan memperoleh pendapatan secara pasti. Hal ini sesuai dengan konsep dasar teori pertukaran (Veithzal, 2008 : 145).

\section{B. Murabahah dalam Literatur Fiqh Muamalah}

1. Defenisi Murabahah

Istilah pembiayaan pada dasarnya lahir dari pengertian I believe, yaitu "saya percaya" atau 'saya menaruh kepercayaan'. Perkataan pembiayaan yang artinya kepercayaan (trust) yang berarti bank menaruh kepada seseorang untuk melaksanakan amanah yang diberikan oleh bank selaku shahibul maal. Dana tersebut harus digunakan dengan benar, adil dan harus disertai dengan ikatan dan syarat-syarat yang jelas serta saling 
menguntungkan bagi kedua belah pihak (Veithzal, 2010 : 698).

Kata murabahah secara bahasa adalah bentuk mutual (bermakna: saling) yang diambil dari bahasa Arab, yaitu ar-ribhu yang berarti kelebihan dan tambahan (keuntungan) (Abdullah, 2004 : 194). Jadi, Murabahah diartikan dengan saling menambah (menguntungkan). Sedangkan dalam definisi para ulama terdahulu adalah jual beli dengan modal asli ditambah keuntungan yang diketahui. Hakikatnya adalah menjual barang dengan harga (modal) yang diketahui penjual dan pembeli dengan tambahan keuntungan yang jelas. Jadi, Murabahah artinya saling mendapatkan keuntungan. Dalam ilmu fiqh, Murabahah diartikan menjual dengan modal asli bersama tambahan keuntungan yang jelas (Abdullah, 2004 : 194).

Secara terminologi, yang dimaksud dengan Murabahah adalah pembelian barang dengan pembayaran yang ditangguhkan (1 bulan, 2 bulan, 3 bulan dan seterusnya tergantung kesepakatan). Pembiayaan murabahah diberikan kepada nasabah dalam rangka pemenuhan kebutuhan produksi (inventory) (Antonio, , 1999 : 25).

Muhammad Syafi'i Antonio mengutip Ibnu Rusyd, mengatakan bahwa murabahah adalah jual beli barang $p$ ada harga asal dengan tambahan keuntungan yang disepakati. Dalam akad ini, penjual harus memberitahu harga produk yang ia beli dan menentukan tingkat keuntungan sebagai tambahannya (Antonio, $2001: 101$ ).

Sedangkan Dwi Suwiknyo mengemukakan bahwa murabahah adalah menjual barang dengan harga jual sebesar harga perolehan ditambah keuntungan yang disepakati dan penjual harus mengungkapkan harga perolehan barang tersebut kepada pembeli. Barang yang diperjual belikan disebut dengan aset murabahah, yaitu aset yang diperoleh dengan tujuan untuk dijual kembali 
Kontrak Pembiayaan Murabahah dan Musawamah

dengan menggunakan akad murabahah.( Suwiknyo, $2010: 29)$.

2. Dalil Murabahah

a. Al-Qur'an

Surah al-Baqarah ayat 275

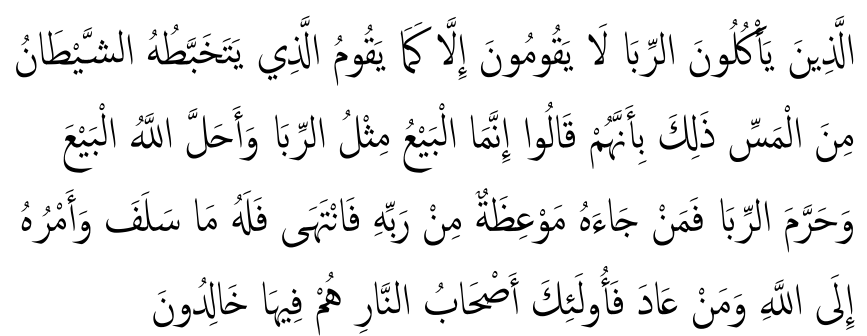

Artinya: Orang-orang yang Makan (mengambil) riba tidak dapat berdiri melainkan seperti berdirinya orang yang kemasukan syaitan lantaran (tekanan) penyakit gila. Keadaan mereka yang demikian itu, adalah disebabkan mereka berkata (berpendapat), Sesungguhnya jual beli itu sama dengan riba, Padahal Allah telah menghalalkan jual beli dan mengharamkan riba. orang-orang yang telah sampai kepadanya larangan dari Tuhannya, lalu terus berhenti (dari mengambil riba), Maka baginya apa yang telah diambilnya dahulu (sebelum datang larangan); dan urusannya (terserah) kepada Allah. orang yang kembali (mengambil riba), Maka orang itu adalah penghuni-penghuni neraka; mereka kekal di dalamnya.(Depag RI, 2004 : 58)

Surah an-Nisa ayat 29:

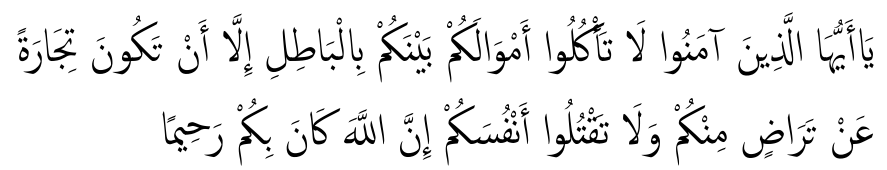

Artinya: Hai orang-orang yang beriman, janganlah kamu saling memakan harta sesamamu dengan jalan yang batil, kecuali dengan jalan perniagaan yang Berlaku dengan suka sama-suka di antara kamu. dan janganlah kamu membunuh dirimu; Sesungguhnya 
Allah adalah Maha Penyayang kepadamu (Depag RI, 2004 : 108).

b. Al-Hadist

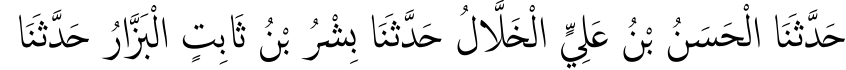

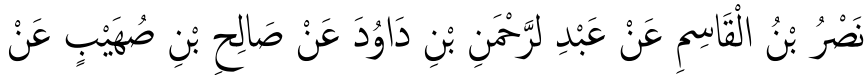

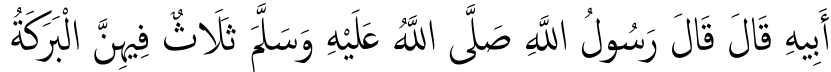

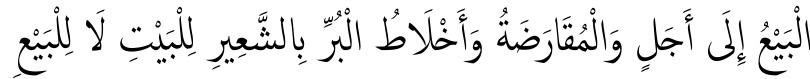

Telah menceritakan kepada kami Al Hasan bin Ali Al Khallal berkata, telah menceritakan kepada kami Bisyr bin Tsabit Al Bazzar berkata, telah menceritakan kepada kami Nashr bin Al Qasim dari 'Abdurrahman bin Dawud dari Shalih bin Shuhaib dari Bapaknya ia berkata, "Rasulullah shallallahu 'alaihi wasallam bersabda: "Tiga hal yang di dalamnya terdapat barakah; jual beli yang memberi tempo, peminjaman, dan campuran gandum dengan jelai untuk di konsumsi orang-orang rumah bukan untuk dijual." (HR. Ibnu Majah )

c. Himpunan Fatwa Dewan Syari'ah Nasional

Dewan Syari'ah Nasional menetapkan beberapa aturan tentang murabahah sebagaimana berikut: 1) Fatwa DSN MUI Nomor 04/DSN-MUI/ IV/2000 tertanggal 1 April 2000 tentang Murabahah

2) Fatwa DSN MUI Nomor 13/DSN-MUI/ IX/2000 tertanggal 16 September 2000 tentang Uang Muka dalam Murabahah

3) Fatwa DSN MUI Nomor 16/DSN-MUI/ IX/2000 tertanggal 16 September 2000 tentang diskon dalam Murabahah

4) Fatwa DSN MUI Nomor 23/DSN-MUI/ III/2005 tertanggal 28 Maret 2002 tentang Potongan Pelunasan Murabahah

5) Fatwa DSN MUI Nomor 46/DSN-MUI/ II/ 2005 tertanggal 17 Februari 2005 tentang Potongan Tagihan Murabahah 
6) Fatwa DSN MUI Nomor 47/DSN-MUI/ II/ 2005 tertanggal 22 Februari 2005 tentang Penyelesaian Piutang Murabahah bagi Nasabah tidak Mampu Membayar

7) Fatwa DSN MUI Nomor 48/DSN-MUI/ II/2005 tertanggal 25 Februari 2005 tentang Penjadwalan kembali Tagihan Murabahah

8) Fatwa DSN MUI Nomor 49/DSN-MUI/ II/ 2005 tertanggal 25 Februari 2005 tentang Konversi Akad Murabahah

3. Rukun dan Syarat Murabahah

Adapun rukum murabahah yaitu:

a. $B a^{\prime} i u$ (penjula)

b. Musytari (pembeli)

c. Mabi' (barang yang diperjual belikan)

d. Tsaman (harga barang)

e. Ijab qabul (pernyataan serah terima).

Dalam hal ini ijab qabul yang dimaksud adalah salah satu bentuk indikasi yang meyakinkan adanya rasa suka sama suka. Bila pada waktu ini kita dapat menemukan cara lain yang dapat ditempatkan sebagai indikasi seperti saling mengangguk atau saling menandatangani suatu dokumen (Syarifuddin, 2010 : 195).

Sedangkan syarat murabahah yauitu:

a. Syarat yang berakad (ba'iu dan musytari) cakap hukum dan tidak dalam keadaan terpaksa.

b. Barang yang diperjual belikan (mabi') tidak termasuk barang yang haram dan jenis maupun jumlahnya jelas

c. Harga barang (tsaman) harus dinyatakan secara transparan (harga pokok dan komponen keuntungan) dan cara pembayarannya disebutkan dengan jelas

d. Pernyataan serah terima (ijab qabul) harus jelas dengan menyebutkan secara spesifik pihak-pihak yang berakad (Veitthzal, 2008 : 146).

Wahbah az-Zuhaili mengatakan bahwa dalam 
jual beli murabahah itu disyaratkan beberapa hal, yaitu:

a. Mengetahui harga pokok

Dalam jual beli murabahah disyaratkan agar pembeli mengetahui harga pokok atau harga asal, karena m engetahui h arga merupakan syarat sah jual beli. Syarat ini juga diperuntukkan bagi jual beli attauliyyah dan al-wadhi'ah.

b. Mengetahui keuntungan

Hendaknya margin keuntungan juga diketahui oleh pembeli, karena margin keuntungan tersebut termasuk bagian dari harga, sedangkan mengetahui harga merupakan syarat sah jual beli.

c. Harga pokok merupakan sesuatu yang dapat diukur, dihitung dan ditimbang, baik pada waktu terjadi jual beli dengan penjual dengan penjual yang pertama atau setelahnya (az-Zuhaili, 1989: 705).

4. Asas-asa Akad Pembiayaan Murabahah

Sebagaimana dalam hukum perjanjian menurut KUHP Perdata yang mengenal asa kebebasan berkonrak, asas personalitas dan asas iktikad baik, sedangkan dalam hukum adat mengenal asas terang, tunai dan rill, dalam hukum islam juga mengenal asasasas hukum perjanjian, yaitu sebagai berikut:

a. Al-Hurriyah (kebebasan)

Asas ini merupakan prinsip dasar dalam hukum perjanjian islam, dalam artian para pihak bebas dalam membuat sesuatu perjanjian atau akad. Bebas dalam menentukan objek akad dan bebas menentukan dengan siapa ia akan membuat perjanjian, serta bebas menentukan bagaimana menentukan penyelesaian sengketa jika terjadi dikemudian hari.

b. Al-Musawah (persamaan atau kesetaraan)

Asas ini mengandung pengertian bahwa para pihak mempunyai kedudukan yang sama, sehingga dalam menentukan term and condition dari suatu akad setiap pihak mempunyai kesetaraan atau kedudukan yang seimbang. 
c. Al-'adalah (keadilan)

Pelaksanaan asas ini dalam suatu akad menuntut para pihak melakukan yang benar dalam pengungkapan kehendak dan keadaan, dan memenuhi semua kewajibannya. Akad harus senantiasa mendatangkan keuntungan yang adil dan seimbang, serta tidak boleh mendatangkan kerugian bagi salah satu pihak.

d. Al-Ridha (kerelaan)

Asas ini menyatakan bahwa segala transaksi yang dilakukan harus atas dasar kerelaan antara masingmasing pihak, tidak boleh ada unsur paksaan, tekanan dan penipuan.

e. Ash-hidiq (kebenaran atau kejujuran)

Agama islam melarang manusia melakukan kebohongan dan penipuan, karena dengan adanya kebohongan dan penipuan sangat berpengaruh pada keabsahan akad. Akad yang di dalamnya mengandung kebohongan atau penipuan memberikan hak pada pihak lain untuk menghentikan proses pelaksanaan akad tersebut.

f. Al-Kitabah (tertulis)

Setiap akad hendaknya dibuat secara tertulis, karena demi kepentingan pembuktian jika dikemudian hari terjadi sengketa (Bagya, 2012 : 5051).

\section{Murabahah dalam Fatwa DSN dan PBI}

Dalam fatwa DewanSyariah Nasional Nomor 04/ DSN- MUI/IV/2000 tanggal 1 A p ril 2000, d ipaparkan tentang k etentuan umum murabahah sebagai berikut:

1. Ketentuan umum murabahah dalam bank syariah adalah sebagai berikut:

a. Bank dan nasabah harus melakukan akad murabahah yang b ebas riba.

b. Barang yang diperjual belikan tidak diharamkan oleh syariah Islam.

c. Bank membiayai sebagian atau seluruh harga pembelian barang yang telah disepakati 
kualifikasinya.

d. Bank membeli barang yang diperlukan nasabah atas nama bank sendiri, dan pembelian ini harus sah dan bebas riba.

e. Bank harus menyampaikan semua hal yang berkaitan dengan pembelian, misalnya jika pembelian dilakukan secara berhutang.

f. Bank kemudian menjual barang tersebut kepada nasabah (pemesan) dengan harga jual senilai harga beli ditambah keuntungan. Dalam hal ini, bank harus memberitahu secara jujur harga pokok barang kepada nasabah berikut biaya yang diperlukan.

g. Nasabah membayar harga barang yang telah disepakati tersebut pada jangka waktu tertentu yang telah disepakati.

h. Untuk mencegah terjadinya penyalahgunaan atau kerusakan akad tersebut, pihak bank dapat mengadakan perjanjian khusus dengan nasabah.

i. Jika bank hendak mewakilkan kepada $\mathrm{n}$ asabah u ntuk membeli barang dari pihak ketiga, akad jual beli murabahah harus dilakukan setelah barang secara prinsip menjadi milik bank.

2. Ketentuan murabahah kepada nasabah

a. Nasabah mengajukan permohonan dan perjanjian pembelian suatu barang atau asset kepada bank.

b. Jika bank menerima permohonan tersebut, ia harus membeli terlebih dahulu aset yang dipesannya secara sah dengan pedagang.

c. Bank kemudian menawarkan aset tersebut kepada nasabah dan nasabah harus menerima atau membelinya sesuai dengan pernjanjian yang telah disepakati, karena secara hukum, perjanjian tersebut mengikat kemudian kedua belah pihak harus membuat kontrak jual beli.

d. Dalam jual beli ini bank dibolehkan meminta nasabah untuk membayar uang muka saat menandatangani kesepakatan awal pemesanan.

e. Jika nasabah kemudian menolak membeli barang tersebut, biaya riil bank harus dibayar dari uang 
muka tersebut.

f. Jika nilai uang muka ku rang dari kerugian yang $h$ arus $d$ itanggung oleh $b$ ank, bank $d$ apat meminta kemnbali sisa kerugiannya kepada nasabah.

g. Jika uang muka memakai kontrak urbun sebagai alternatif dari uang muka, maka:

1. Jika nasabah memutuskan untuk membeli barang tersebut, ia tinggal membayar sisa harga.

2. Jika nasabah batal membeli, uang muka menjadi milik bank maksimal sebesar kerugian yang ditanggung oleh bank akibat pembatalan tersebut $\mathrm{d}$ an jika $\mathrm{u}$ ang $\mathrm{muka}$ tidak mencukupi, nasabah wajib melunasi kekurangannya.

3. Jaminan dalam murabahah

a. Jaminan dalam murabahah dibolehkan, agar nasabah serius dengan pesanannya.

b. Bank dapat meminta nasabah untuk menyediakan jaminan yang dapat dipegang.

4. Hutang dalam murabahah

a. Secara prinsip, penyelesaian hutang nasabah dalam transaksi murabahah tidak ada kaitannya dengan transaksi lain yang dilakukan nasabah dengan pihak ketiga atas barang tersebut. Jika nasabah menjual kembali barang tersebut dengan keuntungan atau kerugian, ia tetap berkewajiban untuk menyelesaikan hutangnya kepada bank.

b. Jika nasabah menjual barang tersebut sebelum masa angsuran berakhir, ia tidak wajib segera melunasi seluruhnya.

c. Jika penjualan barang tersebut menyebabkan kerugian, nasabah tetap harus menyelesaikan hutangnya sesuai kesepakatan awal. Ia $\mathrm{t} i$ dak boleh memperlambat pembayaran-pembayaran angsuran atau meminta kerugian itu diperhitungkan.

5. Penundaan pembayaran dalam murabahah:

a. Nasabah yang memiliki kemampuan tidak dibenarkan menunda penyelesaian hutangnya. 
b. Jika nasabah menunda-nunda pembayaran dengan sengaja, atau jika salah satu pihak tidak menunaikan kewajibannya, maka penyelesaiannya dilakukan melalui Badan Arbitrase Syariah setelah tidak tercapai kesepakatan melalui musyawarah (MUI, 2004 : 64-66).

Sedangkan dalam peraturan Bank Indonesia terdapat beberapa aturan yang berkaitan dengan murabahah diantara nya:

1. Defenisi murabahah disebutkan bahwa murabahah yaitu, adalah transaksi jual beli suatu barang sebesar harga perolehan barang ditambah dengan margin yang disepakati oleh para pihak, dimana penjual menginformasikan terlebih dahulu harga perolehan kepada pembeli (Peraturan Bank Indonesia Nomor 9/19/PBI/2007 Tanggal 17 Desember 2007).

2. Penyaluran dana dalam bentuk pembiayaan berdasarkan Murabahah berlaku persyaratan paling kurang sebagai berikut :

a. Bank menyediakan d ana pembiayaan be r dasarkan perjanjian jual beli barang.

b. jangka waktu pembayaran harga barang oleh nasabah kepada Bank ditentukan berdasarkan kesepakatan Bank dan nasabah;

c. Bank dapat membiayai sebagian atau seluruh harga pembelian barang yang telah disepakati kualifikasinya;

d. dalam hal Bank mewakilkan kepada nasabah (wakalah) untuk membeli barang, maka Akad Murabahah harus dilakukan setelah barang secara prinsip menjadi milik Bank;

e. Bank dapat meminta nasabah untuk membayar uang muka atau urbun saat menandatangani kesepakatan awal pemesanan barang oleh nasabah;

f. Bank dapat meminta $\mathrm{n}$ a s a b a h untuk menyediakan agunan tambahan selain barang yang dibiayai Bank;

g. kesepakatan marjin harus ditentukan satu kali pada awal Akad dan tidak berubah selama periode Akad; 
h. Angsuran pembiayaan selama periode Akad harus dilakukan secara proporsional;

3. Dalam hal Bank meminta nasabah untuk membayar uang muka atau urbun maka berlaku ketentuan sebagai berikut :

a. dalam hal uang muka, jika nasabah menolak untuk membeli barang setelah membayar uang muka, maka biaya riil Bank harus dibayar dari uang muka tersebut dan bank harus mengembalikan kelebihan uang muka kepada nasabah. Namun jika nilai uang muka kurang dari nilai kerugian yang harus ditanggung oleh Bank, maka Bank dapat meminta lagi pembayaran sisa kerugiannya kepada nasabah;

b. dalam hal urbun, jika nasabah batal membeli barang, maka urbun yang telah dibayarkan nasabah menjadi milik Bank maksimal sebesar kerugian yang ditanggung oleh Bank akibat pembatalan tersebut, $\mathrm{dan}$ jika urbun tidak mencukupi, nasabah wajib melunasi kekurangannya.

4. Dalam pembiayaan Murabahah Bank dapat memberikan potongan dari total kewajiban $\mathrm{p}$ e $\mathrm{m}$ b a y a r a $\mathrm{n}$ $\mathrm{h}$ a nya kepada nasabah yang telah melakukan kewajiban pembayaran cicilannya dengan tepat waktu dan/atau nasabah yang mengalami penurunan kemampuan pembayaran.

5. Besar potongan Murabahah kepada nasabah tidak boleh diperjanjikan dalam Akad dan diserahkan kepada kebijakan Bank (Peraturan Bank Indonesia Nomor: 7-46 - PBI-2005 Tanggal 14 November 2005).

\section{Struktur Murabahah dalam LKS}

Unsur yang membedakan bank syari'ah dengan bank konvensional adalah keharusan adanya Dewan Pengawas Syari'ah (DPS) yang berada dalam naungan Dewan Syari'ah Nasional Majelis Ulama Indonesia (DSN-MUI). Dewan Pengawas Syari'ah (DPS) ini berfungsi mengawasi beroperasinya bank dan produk- 
produk yang dikeluarkannya agar tetap sesuai dengan ketentuan syari'ah.

Dalam menunjang kelangsungan usahanya, baik perorangan maupun perusahaan memerlukan dana yang cukup untuk membiayai seluruh kegiatan operasi dan pada akhirnya untuk mencapai salah satu tujuan usaha berupa perolehan keuntungan. D alam operasionalnya bank konvensional memberikan k redit kepada peminjam atau debitur, sedangkan bank syari'ah memberikan pembiayaan kepada nasabah yang akan dibiayai atau mitra.

Murabahah adalah akad jual beli barang sebesar harga pokok barang ditambah dengan margin keuntungan yang disepakati. Berdasarkan akad jual beli tersebut bank membeli barang yang dipesan oleh dan menjualnya kepada nasabah. Harga jual bank adalah harga beli dari supplier ditambah keuntungan yang disepakati. Bank harus memberi tahu secara jujur harga pokok barang kepada nasabah berikut biaya yang diperlukan. Murabahah dapat dilakukan berdasarkan pesanan atau tanpa pesanan. Dalam murabahah berdasarkan pesanan, bank melakukan pembelian barang setelah ada pemesanan dari nasabah. Murabahah berdasarkan pesanan dapat bersifat mengikat atau tidak mengikat nasabah untuk membeli barang yang dipesannya. Pembayaran murabahah dapat dilakukan secara tunai atau cicilan (Muhammad,, 2014 : 271).

Secara umum, aplikasi perbankan dari Murabahah dapat digambarkan dalam skema berikut ini (Antonio, 107):

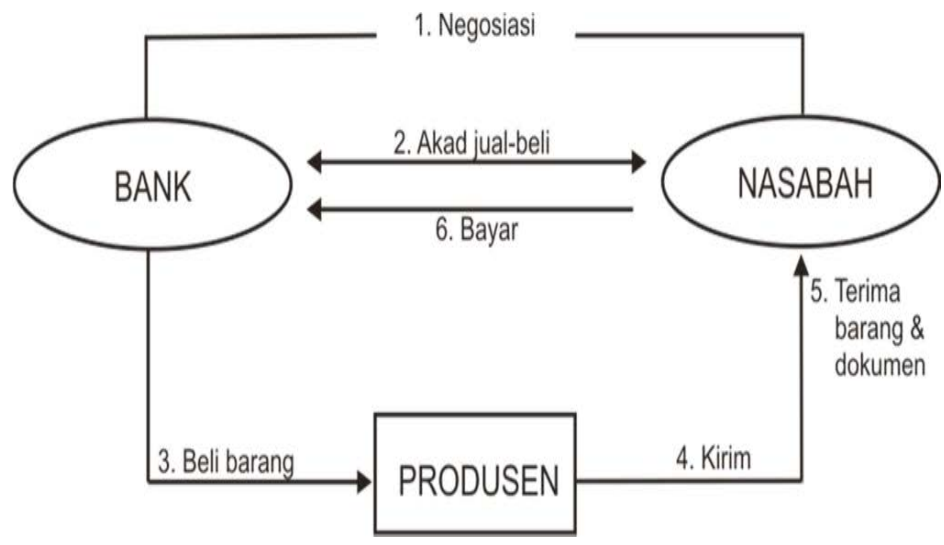


Menurut Adiwarman Karim, mu rabahah dalam praktek perbankan dapat dibedakan menjadi dua macam, yaitu:

a. Murabahah dengan pesanan

Murabahah dapat dilakukan berdasarkan pesanan atau tanpa pesanan. Dalam murabahah berdasarkan pesanan, bank melakukan pembelian barang setelah ada pemesanan dari nasabah dan dapat bersifat mengikat atau tidak mengikat nasabah untuk membeli barang yang dipesannya (bank $\mathrm{d}$ apat meminta uang muka pembelian kepada nasabah).

b. Murabahah tunai atau cicilan

Pembayaran murabahah dapat dilakukan secara tunai atau cicilan. Dalam murabahah juga diperkenankan adanya perbedaan dalamharga barang untuk cara pembayaran yang berbeda. Murabahah muajjal dicirikan dengan adanya penyerahan barang diawal akad dan pembayarannya kemudian (setelah awal akad), baik dalam bentuk angsuran maupun dalam bentuk lump sum (sekaligus) (Adiwarman, $2006: 115: 116)$.

Dalam hal keterlambatan pembayaran yang dilakukan oleh nasabah, secara fiqh belum diatur secara terperinci. Ulama sepakat bahwa apabila terjadi k eterlambatan pembayaran, pihak bank diperbolehkan mengenakan sistem denda ( $\left.{ }^{\prime}{ }^{\prime} z i r\right)$ dengan tujuan agar pihak nasabah lebih bertanggung jawab atas dana pinjaman tersebut. Lebih terperinci peraturan tersebut dijelaskan dalam restrukturisasi bank syari'ah. Adapun tahapan restrukturisasi adalah sebagai berikut:

a. Penjadwalan kembali (Rescheduling)

Adalah perubahan jadwal pembayaran kewajiban nasabah atau jangka waktunya.

b. Persyaratan kembali (Reconditioning)

Perubahan sebagian atau seluruh persyaratan pembiayaan tanpa menambah sisa pokok kewajiban nasabah yang harus dibayarkan kepada nasabah, meliputi: pertama: Perubahan jadwal 
pembayaranPerubahan jumlah angsuran, kedua: Perubahan jangka waktu, ketiga: Perubahan nisbah dalam pembiayaan mudharabah atau musyarakah. Keempat: Perubahan proyeksi bagi hasil dalam pembiayaan mudharabah atau musyarakah. Kelima: Pemberian potongan

c. Penataan kembali (Restructuring)

Merupakan perubahan persyaratan pembiayaan, meliputi : pertama: Penambahan dana fasilitas pembiayaan bank. Kedua: Konversi akad pembiayaan. Ketiga: Konversi pembiayaan menjadi surat berharga syari'ah berjangka waktu dan menengah. Keempat: Konversi pembiayaan menjadi penyertaan modal semetara pada perusahaan nasabah.

Selama akad belum berakhir maka harga jual beli tidak boleh berubah, Apabila terjadi perubahan maka akad tersebut menjadi batal. Dalam prakteknya nasabah yang memesan menunjuk pemasok yang telah diketahuinya menyediakan barang dengan spesifikasi dan harga yang sesuai dengan keinginannya. Atas dasar itulah bank melakukan pembelian secara tunai dari pemasok yang dikehendaki oleh nasabahnya, kemudian menjualnya secara tangguh kepada nasabah yang bersangkutan (Arifin, $2006: 23)$.

\section{E. Musawamah (tawar menawar) sebagai model Pembiayaan}

Banyak kalangan ahli fiqih yang lebih menyukai sistem jual beli dengan tawar menawar daripada jual beli dengan sistem fixed profit. Karena sistem fixed profit itu didasari oleh kejujuran dan sikap amanah, yakni jual beli yang bersikap amanah dan kepolosan, sehingga hal itu membutuhkan perhatian terhadap situasi dan kondisi secermat mungkin. Padahal amatlah sulit menghindari dorongan hawa nafsu untuk melakukan tindakan interpretatif dan manipulatif. Jual beli semacam itu lebih baik dihindari (al-Mushlih, 196).

Bank-bank syariah umumnya mengadopsi murabahah untuk memberikan pembiayaan jangka 
pendek kepada para nasabah guna pembelian barang meskipun mungkin sinasabah tidak memiliki uang untuk membayar. Murabahah sebagaiamana yang digunakan dalam perbankan syariah didasarkan pada dua elemen pokok: harga beli serta biaya yang terkait, dan kesepakatan atas mark-up (laba). Ciri dasar kontrak murabahah (sebagai jual beli dengan pembayaran tunda) adalah sebagai berikut:

1. Sipembeli harus memilki pengetahuan tentang biaya-biaya terkait dan tentang harga asli barang, dan batas laba (mark-up) harus ditetapkan dalam bentuk presentase dari total harga plus biayabiayanya.

2. Apa yang dijual adalah barang atau komoditas dan dibayar dengan uang.

3. Apa yang diperjual belikan harus ada dan dimiliki oleh sipenjual dan sipenjual harus mampu menyerahkan barang itu kepada sipembeli.

4. Pembayarannya ditangguhkan.

Bank syariah pada umumnya telah menggunakan murabahah sebagai metode pembiayaan mereka yang utama, meliputi kira-kira tujuh lima persen dari total kekayaan mereka. Sejumlah alasan diajukan untuk menjelaskan popularitas murabahah dalam operasi invesatasi perbankan Islam:

1. Murabahah adalah suatu mekanisme investasi jangka pendek dan dibandingkan dengan sistem profit and loss sharing (PLS) cukup memudahkan;

2. Mark-up dalam murabahah dapat ditetapkan sedemikan rupa sehingga memastikan bahwa bank dapat memperoleh keuntungan yang sebanding dengan keuntungan bank-bank berbasis bunga yang menjadi saingan bank-bank Islam;

3. Murabahah menjauhkan ketidakpastian yang ada pada pendapatan dari bisnis-bisnis dengan profit and loss sharing (PLS);

4. Murabahah tidak memungkinkan bank-bank Islam untuk mencampuri manajemen bisnis, karena bank bukanlah mitra sinasabah, sebab hubungan 
mereka dalam murabahah adalah hubungan antara kreditur dan debitur (Muhammad, 2004 : 154).

Dalam hal proses pembayaran, murabahah dapat dilakukan secara tunai atau tangguh. Pembayaran tangguh adalah pembayaran yang dilakukan tidak pada saat barang diserahkan kepada sipembeli, tetapi dilakukan dalam bentuk angsuran atau sekaligus pada waktu tertentu. Akad murabahah memperkenankan penawaran harga yang berbeda untuk cara pembayaran yang berbeda sebelum akad murabahah dilakukan. Namun jika akad tersebut telah disepakati hanya ada satu harga (harga dalam akad) yang digunakan. Perlu diperhatikan bahwa harga yang disepakati dalam murabahah adalah harga jual, sedangkan biaya perolehan harus diberitahukan. jika penjual mendapatkan diskon sebelum akad murabahah, potongan itu merupakan hak pembeli. Adapun diskon yang diterima setelah akad murabahah disepakati sesuai dengan yang diatur dalam akad, dan jika tidak diatur dalam akad maka potongan tersebut adalah hak penjual. Jika diberlakukan diskon, diskon yang terkait dengan pembelian barang meliputi:

1. Diskon dalam bentuk apapun dari pemasok atas pembelian barang

2. Diskon biaya asuransi dari perusahaan asuransi dalam rangka pembelian barang

3. Komisi dalam bentuk apapun yang diterima terkait dengan pembelian barang. Selain itu diskon atas pembelian barang yang diterima setelah akad murabahah disepakati diberlakukan seseuai dengan kesepakatan dalam akad tersebut. Jika akad tidak mengatur, diskon tersebut menjadi hak penjual (Suwiknyo, 2010 : 31).

Murabahah sebagai suatu mekanisme jual beli dengan pembayaran tunda, dapat terjadi baik pada harga tunai, dengan menghindari segala bentuk mark-up pengganti waktu yang ditundakan untuk pembayaran, ataupun pada harga tunai plus mark-up untuk pengganti waktu penundaan pembayaran. Para fuqaha tidak mempersoalkan keabsahan jual beli dengan pembayaran 
tunda jenis yang pertama, yaitu pembayaran tunda dengan harga tunai. Perbedaan pendapat dikalangan ulama terjadi pada harga kredit yang lebih tinggi dalam jual beli dengan pembayaran tunda (Muhammad, 2005 : 122).

Dalam konteks perbankan Islam sejumlah argumen telah diajukan untuk mendukung keabsahan harga kredit yang lebih tinggi dalam pembayaran tunda diantaranya:

1. Bahwa teks-teks syariah tidak melarangnya

2. Bahwa ada perbedaan antara uang yang tersedia sekarang dengan yang tersedia dimasa yang akan datang seperti yang dikatakan oleh Ali alKhafif seorang faqih kontemporer yang dikutip oleh Muhammad "kebiasaannya (urf) uang yang dibayarkan kontan mempunyai nilai yang lebih tinggi daripada uang yang diberikan pada masa yang akan datang"

3. Bahwa kenaikan harga ini bukan sebagai imbalan waktu tunda pembayaran, dan karena nya tidak tidak sama dengan riba pra islam yang diharamkan al-qur'an

4. Bahwa kenaikan harga dikenakan pada saat penjualan, tidak setelah penjualan terjadi

5. Bahwa kenaikan harga disebabkan faktor-faktor yang mempengaruhi pasar, seperti permintaan dan penawaran, dan naik turunnya daya beli uang sebagai akibat inflasi dan deflasi (Muhammad, 2005 : 121).

Penjual pada prinsipnya, bebas untuk menetapkan harga barang-barangnya, jika harga-harga ini terlalu tinggi, pembeli boleh untuk tidak membelinya atau mencari penggantinya, atau penjual lain boleh masuk kepasar untuk menciptakan keseimbangan harga.

\section{F. Kesimpulan}

Murabahah adalah menjual barang dengan harga jual sebesar harga perolehan ditambah keuntungan yang disepakati dan penjual harus mengungkapkan harga 
perolehan barang tersebut kepada pembeli. Barang yang diperjual belikan disebut dengan aset murabahah, yaitu aset yang diperoleh dengan tujuan untuk dijual kembali dengan menggunakan akad murabahah

Menurut Adiwarman Karim, mu rabahah dalam praktek perbankan dapat dibedakan menjadi dua macam, yaitu:

a. Murabahah dengan pesanan

Murabahah dapat dilakukan berdasarkan pesanan atau tanpa pesanan. Dalam murabahah berdasarkan pesanan, bank melakukan pembelian barang setelah ada pemesanan dari nasabah dan dapat bersifat mengikat atau tidak mengikat nasabah untuk membeli barang yang dipesannya (bank dapat meminta uang muka pembelian kepada nasabah).

b. Murabahah tunai atau cicilan

Pembayaran murabahah dapat dilakukan secara tunai atau cicilan. Dalam murabahah juga diperkenankan adanya perbedaan dalamharga barang untuk cara pembayaran yang berbeda. Murabahah muajjal dicirikan dengan adanya penyerahan barang diawal akad dan pembayarannya kemudian (setelah awal akad), baik dalam bentuk angsuran maupun dalam bentuk lump sum (sekaligus)

Dalam hal keterlambatan pembayaran yang dilakukan oleh nasabah, secara fiqh belum diatur secara terperinci. Ulama sepakat bahwa apabila terjadi k eterlambatan pembayaran, pihak $b$ ank diperbolehkan mengenakan sistem denda ( $\left.t a^{\prime} z i r\right)$ dengan tujuan agar pihak nasabah lebih bertanggung jawab atas dana pinjaman tersebut.

Dalam hal proses pembayaran, murabahah dapat dilakukan secara tunai atau tangguh. Pembayaran tangguh adalah pembayaran yang dilakukan tidak pada saat barang diserahkan kepada sipembeli, tetapi dilakukan dalam bentuk angsuran atau sekaligus pada waktu tertentu. Akad murabahah memperkenankan penawaran harga yang berbeda untuk cara pembayaran yang berbeda sebelum akad murabahah dilakukan. Namun jika akad 
Kontrak Pembiayaan Murabahah dan Musawamah

tersebut telah disepakati hanya ada satu harga (harga dalam akad) yang digunakan. jika penjual mendapatkan diskon sebelum akad murabahah, potongan itu merupakan hak pembeli. Adapun diskon yang diterima setelah akad murabahah disepakati sesuai dengan yang diatur dalam akad, dan jika tidak diatur dalam akad maka potongan tersebut adalah hak penjual 


\section{DAFTAR PUSTAKA}

Abdul Ghofur Anshori, Kapita Selekta Perbankan Syariah di Indonesia, Yogyakarta, UII Press, 2008

Abdullah al-Mushlih dan Shalah ash-Shawi, Figh Ekonomi Keuangan Islam, terj. Abu Umar Basyir, Jakarta, Darul Haq, 2004

Adiwarman A Karim, Bank Islam; Analisis Fiqih dan Keuangan, Jakarta, PT. RajaGrafindo Persada, 2006

Amir Syarifuddin, Garis-garis Besar Fiqh, Jakarta,Kencana, 2010

Bagya Agung Prabowo, Aspek Hukum Pembiayaan Murabahah pada Perbankan Syariah, Yogyakarta,UII Press, 2012

Departemen Agama RI, Al-Qur'an dan Terjemahan, Surabaya, Mekar Surabaya, 2004

Dewan Syariah Nasional MUI, Himpunan Fatwa Keuangan Syariah, Jakarta, Erlangga, 2014

Dwi Suwiknyo, Pengantar Akuntansi Syariah, (Yogyakarta: Pustaka Pelajar, 2010)

Ibnu Majah Abu> Abdullah muhammad bin yazi $>d$ al Qozwaini al-Syahir bi Ibnu Majah, Sunan Ibnu Maja>h, Riyad, Maktabah al ma'arif,tt

Karanaen A. Perwataatmadja dan Muhammad Syafi'i Antonio, Apa dan Bagaimana Bank Islam, Yogyakarta, P.T. Dana Bhakti Prima Yasa, 1999

Muhammad, Manajemen Keuangan Syariah; Analisis Figh $\mathcal{E}$ Keuangan, Yogyakarta,UPP STIM YKPN, 2014 
Kontrak Pembiayaan Murabahah dan Musawamah Manajemen Pembiayaan Bank Syariah, Yogyakarta, UPP AMP YKPN, 2005

Teknik Perhitungan Bagi Hasil dan Princing di Bank Syariah, Yogyakarta:UII Press, 2004

Muhammad Syafi'i Antonio, Bank Islam: Dari Teori ke Praktek, Jakarta, Gema Insani Press, 2001

Veithzal Rivai \& Andria Permata Veithzal, Islamic Financial Management, Jakarta, PT. Rajawali Perss, 2008

Veithzal Rivai \& Arviyan Arifin, Islamic Banking, Jakarta, Bumi Aksara, 2010

Wahbah az-Zuhaili, al-Figh al-Islam wa Adillatuh, Jilid IV, Beirut: Dar al-Fikr, 1989

Zainul Arifin, Dasar-dasar Manajemen Bank Syariah, Jakarta, Pustaka Alvabet, 2006

Peraturan Bank Indonesia Nomor:7-46 -PBI-2005 Tanggal 14 November 2005

Peraturan Bank Indonesia Nomor 13/9/PBI/ 2011

Peraturan Bank Indonesia Nomor 9/19/PBI/2007 Tanggal 17 Desember 2007 